\title{
PENGARUH MODEL PEMBELAJARAN THINK PAIR SHARE BERBASIS TRI KAYA PARISUDHA TERHADAP HASIL BELAJAR IPS
}

\author{
${ }^{1}$ I Made Raka Paryanata, ${ }^{2}$ Anak Agung Gede Agung, ${ }^{3}$ I Made Suarjana \\ 1Jurusan Pendidikan Dasar, Universitas Pendidikan Ganesha, Singaraja, Indonesia \\ 2Jurusan Teknologi Pendidikan, Universitas Pendidikan Ganesha, Singaraja, Indonesia \\ ${ }^{3} J u r u s a n$ Pendidikan Dasar, Universitas Pendidikan Ganesha, Singaraja, Indonesia \\ e-mail: rakaparyanatamade@gmail.com¹, agung2056@undiksha.ac.id², \\ imade.suarjana@undiksha.ac.id ${ }^{3}$
}

\begin{abstract}
ABSTRAK
Sampai saat ini rata-rata hasil belajar IPS siswa di Gugus II Kecamatan Susut yaitu 64,96 dan berada pada kategori rendah sedangkan KKM Nasional 75,00. Rendahnya rata-rata IPS tersebut dipengaruhi oleh banyak faktor baik faktor internal dan eksternal. Salah satu faktor eksternal yang diduga berpengaruh adalah strategi atau model pembelajaran. Oleh karena itu penelitian ini bertujuan untuk mengetahui pengaruh yang signifikan model pelajaran Think Pair Share berbasis Tri Kaya Parisudha terhadap hasil belajar IPS siswa kelas V Gugus II Kecamatan Susut Tahun Pelajaran 2018/2019. Penelitian ini merupakan penelitian quasi experiment dengan desain non-equivalent control group design. Populasi dalam penelitian ini adalah seluruh siswa kelas V SD Gugus II Kecamatan Susut Tahun Pelajaran 2018/2019 yang berjumlah 119 siswa. Sampel diambil dengan teknik Cluster Random Sampling. Sampel dalam penelitian ini yaitu siswa kelas V SD Negeri 1 Pengiangan sebagai kelompok eksperimen yang berjumlah 26 siswa dan siswa kelas V SD Negeri 2 Pengiangan yang berjumlah 22 siswa sebagai kelompok kontrol. Data hasil belajar dikumpulkan dengan metode tes yaitu tes objektif pilihan ganda dengan empat pilihan jawaban $(a, b, c, d)$. Data yang diperoleh dianalisis dengan menggunakan teknik analisis statistik deskriptif dan analisis statistik inferensial (uji-t). Perolehan rata-rata skor pre-test eksperiment adalah 16,19 yang berada pada kategori sedang, dan rata-rata skor pre-test kontrol yaitu 15,9 yang berada pada kategori sedang. Rata-rata skor post-test eksperiment adalah 18,04 yang berada pada kategori tinggi, sedangkan rata-rata post-test kontrol adalah 16,5 yang berada pada kategori sedang. Hasil analisi uji-t diperoleh thitung $=9,167$ dan ttabel (pada taraf signifikansi $5 \%$ ) $=2,021$. Hal ini menunjukkan bahwa thitung > ttabel sehingga $\mathrm{H} 0$ ditolak dan $\mathrm{H} \neg 1$ diterima. Dengan demikian dapat disimpulkan bahwa terdapat pengaruh yang signifikan model pembelajaran Think Pair Share berbasis Tri kaya Parisuda terhadap hasil belajar siswa kelas V SD gusus II Kecamatan Susut Tahun Pelajaran 2018/2019.
\end{abstract}

Kata kunci : Hasil Belajar IPS, Think Pair Share, Tri Kaya Parisudha

\begin{abstract}
Until now the average social studies learning outcomes of student in elementary school were 64,96 and it were in the low category while the national KKM was 75,00 . The low average social studies was influenced by many factors both internal and external factor. One of the
\end{abstract}


suspected external factors was the learning strategy or model. Therefore, this study aimed to determine the significant effect of Think Pair Share based on Tri Kaya Parisudha toward social studies learning outcome students in grade V in Cluster II Susut District in academic year 2018/2019. This research was a quasi-experimental study with a non-equivalent control group design. The population in this study were all 5th grade students in Cluster II Susut District in academic year 2018/2019 in which the students were totaling 119 students. Samples were taken by cluster random sampling technique. The samples in this study were the 5 th grade students of SD Negeri 1 Pengiangan as an experimental group which totaling 26 students while, 22 fifth grade students in SD Negeri 2 Pengiangan as a control group. Learning outcomes data collected by using multiple choice test in which the answers consist of four answer choices (a, b, c, d). The data obtained were analyzed using descriptive statistical analysis techniques and inferential statistical analysis (t-test). The average pre-test sore of experimental group was 16.19 which was in the medium category, and the average pre-test score of control group was 15.9 which was in the medium category. The average post-test score of experimental group is 18.04 which was in the high category, while the average posttest score of control group was 16.5 which was in the medium category. The results of the t-test analysis were thitung $=9,167$ and ttabel (at a significance level of $5 \%$ ) $=2,021$. This showed that thitung $>$ ttabel which made $\mathrm{H} 0$ was rejected dan $\mathrm{H} \neg 1$ was accepted. Therefore, it can be concluded that there was a significant effect of learning model Think Pair Share based on Tri Kaya Parisuda toward student's learning outcome in grade V in Cluster II Susut District in academic year 2018/2019.

Keyword : Social Studies Learning Outcome, Think Pair Share, Tri Kaya Parisudha

\section{PENDAHULUAN}

Salah satu proses yang dapat meningkatkan kualitas sumber daya manusia yaitu melalui pendidikan. Dengan pendidikan, manusia dapat mengembangkan potensi yang ada dalam dirinya. Sehingga potensi yang ada dalam dirinya dapat dioptimalkan dengan baik supaya menciptakan Bangsa yang kokoh. Oleh karena itu, pendidikan sangat berperan penting untuk membantu bangsa menjadi bangsa yang kokoh yang terdiri dari masyarakat yang berpendidikan dan cerdas. Tanpa pendidikan manusia akan sulit berkembang dan bahkan terbelakang karena pendidikan merupakan kebutuhan dari setiap manusia. Undang-Undang No. 20 Tahun 2003 pasal 1 ayat 1 menyatakan bahwa,

pendidikan adalah usaha sadar terencana untuk mewujudkan suasana belajar dan proses pembelajaran agar peserta didik dapat mengembangkan potensi dirinya untuk memiliki kekuatan spiritual keagamaan, pengendalian diri, kepribadian, kecerdasan, akhlak mulia, serta keterampilan yang diperlukan dirinya, masyarakat Bangsa dan Negara.

Menurut Wulandari (2018) mengemukakan bahwa "Pendidikan di Indonesia terdiri dari beberapa jenjang salah satunya jenjang sekolah dasar. Sekolah dasar merupakan jenjang yang paling dasar dalam pendidikan formal di Indonesia". Dalam sekolah dasar terjadi proses pembelajaran yang kompleks, salah satu perubahan mendasar terjadi ditingkat sekolah dasar yaitu terkait dengan system pembelajaran tematik integratif. Kemajuan pendidikan di Indonesia harus sejalan dengan keberhasilan guru dalam menyampaikan materi terhadap siswa.

Berdasarkan pemaparan di atas, dapat ditarik kesimpulan bahwa pendidikan adalah usaha sadar terencana untuk mewujudkan suasana belajar dan proses pembelajaran agar 
peserta didik dapat mengembangkan potensi dirinya dari jenjang yang paling dasar dalam pendidikan formal. Kemajuan pendidikan harus sejalan dengan keberhasilan guru dalam pelaksanaan pembelajaran baik dari tiangkat paling dasar, terutama dalam pembelajaran di sekolah dasar.

Guru adalah salah satu faktor utama yang dapat mempengaruhi proses pembelajaran. Keberadaan guru diharapkan mampu untuk mengembangkan proses belajar dan pembelajaran yang dapat membantu peserta didik untuk memproleh pengetahuan dan keberadaan guru sangat menentukan berhasil tidaknya proses pembelajaran yang diterapkan di sekolah dasar. Menurut Irmayanti (2012:2) menjelaskan bahwa dalam kegiatan belajar mengajar guru merupakan salah satu komponen utama yang sangat berpengaruh terhadap siswa karena guru merupakan ujung tombak tercapainya pendidikan. Namun dalam proses pembelajaran di Indonesia guru masih sulit mencapai tujuan dari pendidikan. Salah satunya pada proses pembelajaran yang terdapat dalam pendidikan dasar yaitu mata pelajaran IImu Pengetahuan Sosial (IPS).

Setiap calon guru kelas maupun guru IPS SD dituntut untuk menguasai berbagai jenis konsep dasar ilmu-ilmu sosial yang memadai agar pembelajaran akan lebih sesuai kebutuhan siswa, kemampuan guru, dan tujuan pendidikan nasional. Tuntutan tersebut muncul dalam rangka untuk pengembangan materi pembelajaran IPS sehingga proses pembelajaran akan lebih menarik dan siswa juga akan lebih antusias. Jadi, seorang guru IPS SD harus menguasai konsep dasar ilmu-ilmu sosial secara mendalam, mengemas dan mengembangannya maka persepsi siswa terhadap pembelajaran IPS akan lebih positif dan secara otomatis siswa akan menyenangi pembelajaran IPS. Namun, penguasaan konsep saja tidak cukup untuk dapat memahami IPS. Guru juga sangat perlu untuk menerapkan strategi pembelajaran yang dapat melibatkan siswa secara langsung dalam setiap kegiatan belajar mengajar di dalam kelas.

IPS adalah ilmu pengetahuan yang mengkaji berbagai disiplin ilmu sosial dan humaniora serta kegiatan dasar manusia yang dikemas secara ilmiah dalam rangka memberi wawasan dan pemahaman yang mendalam pada peserta didik, khususnya di tingkat dasar dan menengah (Susanto, 2013:137). Sedangkan menurut Lasmawan (2010:15), IPS merupakan, "mata pelajaran yang bersumber dari kehidupan sosial masyarakat yang diseleksi dengan menggunakan konsep-konsep ilmu sosial yang digunakan untuk kepentingan pembelajaran."

Berdasarkan pendapat di atas, dapat disimpulkan bahwa IPS adalah sekelompok disiplin ilmu yang mempelajari aspek-aspek yang berhubungan dengan manusia dan lingkungan sosialnya. Tujuan utama dari pembelajaran IPS yaitu membantu mengembangkan kemampuan dan wawasan siswa yang menyeluruh tentang berbagai aspek ilmu sosial dan kemanusiaan. Berdasarkan pengertian dan tujuan dari pembelajaran IPS dapat disimpulkan bahwa IPS sangat penting untuk meningkatkan kualitas sumber daya manusia dibidang nilai, sikap, dan pengetahuan khususnya di kehidupan sosial masyarakat.

Berdasarkan hasil wawancara dan pengumpulan data ditemukan beberapa masalah dalam pembelajaran IPS yang di lakukan pada tanggal 7 sampai 11 januari 2019 di kelas $V$ Gugus II Kecamatan Susut. Wawancara ini dilakukan pada wali kelas V dan ditemukan beberapa masalah yaitu: (1) Rendahnya peran aktif siswa dalam proses pembelajaran, (2) Kurangnya penggunan model pembelajaran yang inovatif dalam proses pembelajaran, (3) Kecendrungan guru menggunakan metode ceramah dalam proses pembelajaran sehingga pembelajaran menjadi berpusat pada guru (teacher center).

Tujuan pembelajaran adalah pencapaian perubahan perilaku pada peserta didik setelah mengikuti kegiatan belajar mengajar (Kosasih, 2014:13). Namun, yang terjadi pada siswa kelas V Gugus II Kecamatan Susut yaitu siswa tidak berhasil mencapai tujuan pembelajaran. Dengan 
kata lain, sasaran akhir yang diharapkan oleh guru di sekolah tersebut tidak tercapai. Hal tersebut dapat dilihat dari nilai hasil belajar IPS siswa yang masih belum mencapai tujuan KKM.

Salah satu solusi yang dapat ditawarkan untuk mengatasi hal tersebut adalah dengan menerapkan model pembelajaran Think Pair Share. Dalam model pembelajaran ini, siswa di tuntut untuk lebih aktif di dalam kelas sedangkan guru hanya sebagai fasilitator. Pendekatan seperti ini disebut sebagai students centered learning atau pembelajaran berpusat pada siswa. Menurut Maryatun dan Kusumadewi (2012), dalam proses pembelajaran yang menggunakan student centered approach, siswa merupakan titik pusat dari proses pembelajaran. Guru memulai pembelajaran dengan memberikan kesempatan yang seluas-luasnya bagi anak untuk mengkonstruksi pengetahuannya melalui pengalaman belajar, bereksplorasi, memberikan kebebasan pada anak untuk memilih kegiatan yang sesuai dengan kebutuhan dan minat anak. Sehingga, melalui pendekatan pembelajaran berpusat pada siswa, guru harus memilih model pembelajaran yang tepat karena sangat berpengaruh terhadap proses pembelajaran siswa untuk menjadikan pembelajaran lebih efektif, bermakna dan menarik. Ada banyak jenis model pembelajaran yang dapat digunakan oleh guru seperti model pembelajaran kooperatif, kontekstual, realistik, berbasis masalah, problem solving dan lain sebagainya.

Menurut Trianto (2007:61), Think Pair Share adalah "jenis pembelajaran koperatif yang dirancang untuk mempengaruhi pola interaksi siswa". Pola interaksi yang di maksud adalah adanya interaksi antara satu siswa dengan siswa lainnya. Sedangkan, tujuan dari metode ini adalah untuk memecahkan suatu masalah yang diberikan oleh guru secara berdiskusi. Think Pair Share adalah suatu model pembelajaran kooperatif yang memberi siswa waktu untuk berfikir dan merespon serta saling membantu satu sama lain." (Shoimin, 2014:8) Dalam penelitian ini, model pembelajaran Think Pair Share akan dimodifikasikan berdasarkan pada salah satu konsep kehidupan Agama Hindu yaitu Tri Kaya Parisudha. Asmariani (2012) menyatakan bahwa Tri Kaya Parisudha merupakan salah satu bagian ajaran Agama Hindu. Tri Kaya Parisudha berasal dari kata tri yang artinya tiga, kaya yang artinya gerak dan parisudha artinya suci. Jadi, Tri Kaya Parisudha berarti tiga perbuatan suci. Ada tiga perilaku manusia yang harus disucikan, yaitu berpikir yang bersih dan suci (manacika), berkata yang benar (wacika) dan berbuat yang jujur (kayika), jadi Tri Kaya Parisudha adalah sebuah upaya pembersihan dan penyucian atas perbuatan manusia.

Berdasarkan kosep dari Tri Kaya Parisudha dengan mengkolaborasikan model pembelajaran Think Pair Share, pembelajaran dikelas dapat digambarkan dengan 3 aktifitas. Budiarta dan Krismayani (2018) menyatakan bahwa peserta didik akan dilatih untuk selalu berpikir yang baik secara individu (Think-Manacika), kemudian mereka akan berdiskusi dengan temannya atau pasangannya (Pair-Wacika) dan diakhiri dengan membagikan gagasan hasil diskusi mereka dengan teman-teman yang lain di dalam kelas dan juga akan diharapkan berlanjut di luar kelas (Share-Kayika). Dengan mengkolaborasikan model pembelajaran dan konsep pembelajaran Agama Hindu diharapkan mampu mempengaruhi hasil belajar IPS siswa. Namun tidak hanya menekankan pada peningkatan hasil belajar IPS, siswa juga dapat mengembangkan karakter- karakter yang mengarah pada pengembangan karakter yang baik sesuai dengan ajaran Tri Kaya Parisudha. Dalam model pembelajaran ini, peneliti juga tidak ada kaitannya dengan proses menghindukan peserta didik non-Hindu tapi peneliti lebih menekankan pada bagaimana siswa dapat menjadikan konsep pembelajaran Agama Hindu sebagai acuan untuk siswa dapat berbuat yang baik dan benar. Selain itu, model pembelajaran Think Pair Share diharapkan dapat memberikan suasana yang menarik bagi siswa.

\section{METODE}

Pengaruh Model Pembelajaran Think Pair Share Berbasis Tri Kaya Parisudha Terhadap 
Penelitian ini bertujuan untuk mengetahui pengaruh model pembelajaran Think Pair Share berbasis Tri Kaya Parisudha terhadap hasil belajar IPS siswa kelas V gugus II Kecamatan Susut. Penelitian ini merupakan jenis penelitian eksperimen semu (quasi eksperiment) karena tidak semua variabel dapat dikontrol secara ketat. Penelitian ini menggunakan rancangan non-equivalent control group desain yang menggunakan pre- test dan post- test. Rancangan penelitian ini diilustrasikan pada Gambar 1.

\begin{tabular}{|cccc|}
\hline $\mathrm{E}:$ & 01 & $\mathrm{X}$ & 02 \\
\hline $\mathrm{K}:$ & 03 & - & 04 \\
\hline
\end{tabular}

Gambar 1 Rancangan penelitian Non-equivalent Control Group Design

Populasi dalam penelitian ini adalah seluruh siswa kelas V SD Gugus II Kecamatan Susut yang berjumlah 6 sekolah dasar. Populasi yang ada dipilih menggunakan teknik cluster random sampling. Cara ini dilakukan karena tidak mungkin mengubah atau mengacak individu, jadi yang dapat dipilih secara acak yakni kelas ataupun kelompok. Kelas dipilih sebagaimana telah terbentuk tanpa campur tangan peneliti.

Berdasarkan hasil cluster random sampling diperoleh sampel, yaitu siswa kelas V SDN 1 Pengiangan yang berjumlah 26 orang dan siswa kelas V SDN 2 Pengiangan yang berjumlah 22 Selanjutnya dilakukan pengundian tahap ke dua untuk menentukan kelas eksperimen dan kelas kontrol.

Instrumen pengumpulan data yang digunakan dalam penelitian ini adalah berupa tes objektif. Soal objektif yang digunakan terdiri dari 30 butir soal. Untuk menentukan butir soal instrumen tersebut layak untuk diberikan terhadap kelompok sampel terlebih dahulu dilakukan uji coba. Uji coba tes hasil belajar IPS meliputi: validitas butir tes, reliabilitastes tes, daya beda tes, dan tingkat kesukaran tes. Analisis data dalam penelitian ini dilakukan dalam tiga tahap. Pada tahap pertama dilakukan analisis deskriptif, tahap kedua digunakan analisis uji coba prasyarat untuk pembuktian persyaratan analisis statistik. Sedangkan pada tahap ketiga dilakukan analisis untuk pembuktian hipotesis namun sebelum uji hipotesis dilakukan diuji terlebih dahulu gain schore hasil belajar pada pre test dan post test.

Pengujian terhadap hipotesis penelitian yang telah dirumuskan dilakukan melalui metode statistika, hipotesis pertama dilakukan dengan menggunakan analisis Uji Independent Sample t-test. Sebelum dilakukan uji hipotesis terlebih dahulu dilakukan uji prasyarat analisis yang meliputi uji normalitas sebaran data, uji homogenitas varians dan perhitungan gain schore.

\section{HASIL DAN PEMBAHASAN}

Data penelitian ini adalah skor hasil belajar siswa melalui pre-test sebelum diberikannya perlakuan pada kelas eksperimen serta kelas kontrol dan skor hasil belajar melalui post-tes setelah diberikan perlakuan berupa penerapan model pembelajaran Think Pair Share berbasis Tri Kaya Parisudha pada kelompok eksperimen dan bukan penerapan model pembelajaran Think Pair Share Berbasis Tri Kaya Parisudha pada kelompok kontrol.

Hasil pre-test yang dilakukan pada kelompok eskperimen dengan jumlah siswa sebanyak 26 siswa menunjukkan bahwa skor tertinggi adalah 25, skor terendah adalah 7 , mean $(\mathrm{M})=16,19 ;$ median $(\mathrm{Md})=17 ; \operatorname{modus}(\mathrm{Mo})=18,94$; varians $\left(\mathrm{s}^{2}\right)=4,45$; dan standar $\operatorname{deviasi}(\mathrm{s})=2,11$. 


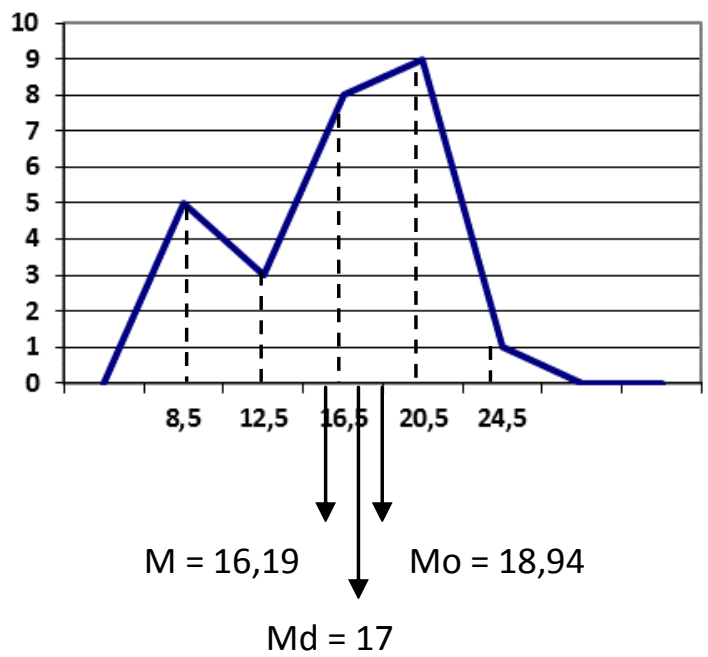

Gambar 2 Kurve Poligon Hasil Belajar IPS Pre-Test Kelompok Eksperimen

Sedangkan, hasil post-test terhadap 26 orang siswa kelompok eksperimen menunjukkan bahwa skor tertinggi adalah 27, skor terendah adalah 8 , mean $(\mathrm{M})=18,04$; median $(\mathrm{Md})=18,5 ;$ modus $(\mathrm{Mo})=20,02$; varians $\left(\mathrm{s}^{2}\right)=23,56$; dan standar deviasi $(\mathrm{s})=4,85$.

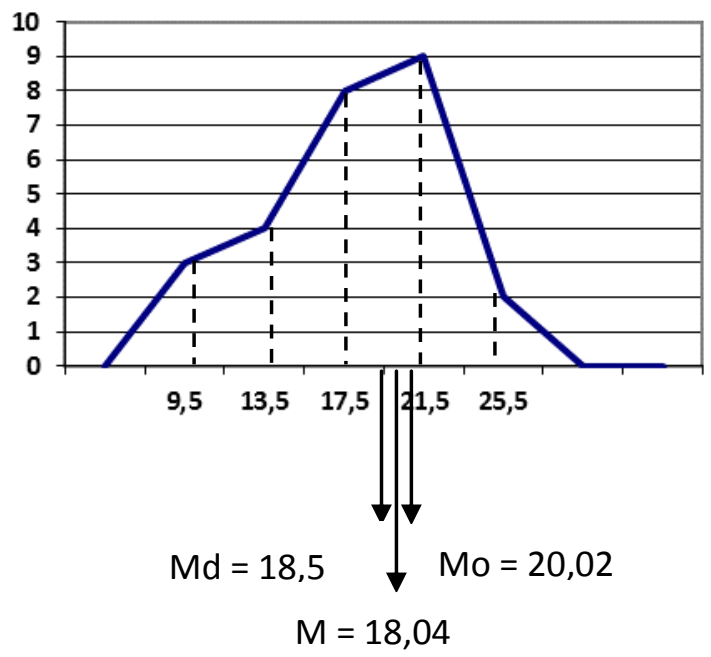

Gambar 3 Kurva Poligon Data Post-Test Hasil Belajar IPS Siswa Kelompok Eksperimen

Berdasarkan rata - rata nilai pada hasil pre test dan post test siswa, dapat disimpulkan bahwa nilai post test siswa lebih besar dari nilai pre testnya. Sementara pada kelas kontrol diperoleh hasil pre-test yang dilakukan pada kelompok kontrol dengan jumlah siswa sebanyak 26 siswa menunjukkan bahwa skor tertinggi adalah 25, skor terendah adalah 7 , mean $(\mathrm{M})=$ 15,9; median $(\mathrm{Md})=15,4$; modus $(\mathrm{Mo})=14,5$; varians $\left(\mathrm{s}^{2}\right)=14,6$; dan standar deviasi $(\mathrm{s})=$ 3,75 . 


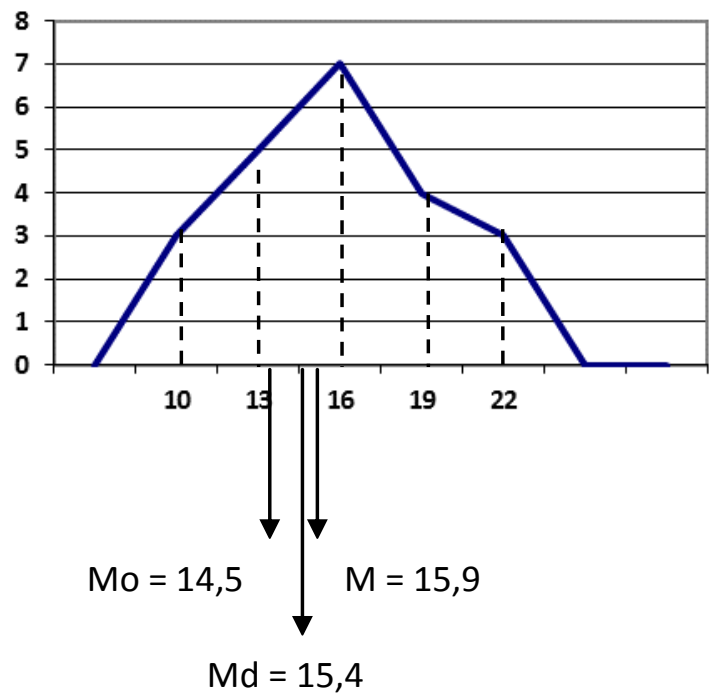

Gambar 4 Kurve Poligon Data Pre-Test Hasil Belajar IPS Siswa Kelompok Kontrol

Sementara hasil post-test terhadap 22 orang siswa kelompok kontrol menunjukkan bahwa skor tertinggi adalah 23, skor terendah adalah 8 , mean $(M)=16,5$; median $(\mathrm{Md})=16,5$; modus $(\mathrm{Mo})=15$; varians $\left(\mathrm{s}^{2}\right)=18,17$; dan standar deviasi $(\mathrm{s})=4,26$.

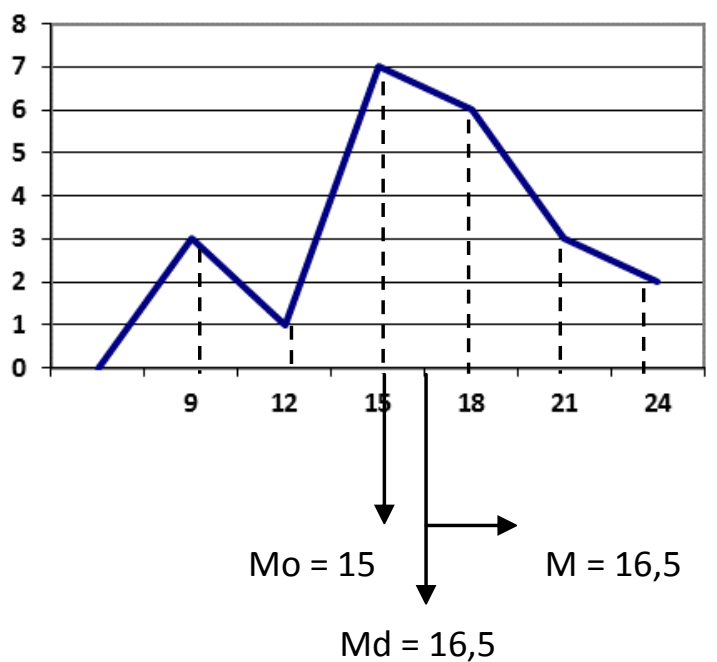

Gambar 5 Kurva Poligon Data Hasil Belajar IPS Post-Test Kelompok Kontrol

Berdasarkan hasil pre-test dan post-test pada kelompok kntrol diperoleh kesimpulan bahwa skor post-test siswa lebih besar daripada skor pre-test siswa.

Sebelum melakukan uji hipotesis terlebih dahulu dilakukan uji prasyarat. Adapun uji prayasar yang pertama yaitu menguji normalitas data. Berdasarkan hasil perhitungan dengan menggunakan rumus Chi Squre, diperoleh $\chi^{2}$ hitung skor Hasil Belajar IPS siswa kelompok eksperimen adalah 2,127, sedangkan $\chi_{\text {tabel }}^{2}$ dengan taraf signifikansi $5 \%$ dan $\mathrm{dk}=2$ adalah 5,99. Hal ini berarti, $\chi^{2}{ }_{\text {hitung }}$ skor Hasil Belajar IPS siswa kelompok eksperimen lebih kecil dari $\chi_{\text {tabel }}^{2}\left(\chi_{\text {hitung }}^{2}<\chi_{\text {tabel }}^{2}\right)$, sehingga data Hasil Belajar IPS siswa kelompok eksperimen 
berdistribusi normal. Selanjutnya, $\chi^{2}$ hitung skor Hasil Belajar IPS siswa kelompok kontrol adalah 4,557 dan $\chi_{\text {tabel }}^{2}$ dengan taraf signifikansi $5 \%$ dan $\mathrm{dk}=2$ adalah 5,99. Hal ini berarti, $\chi^{2}{ }_{\text {hitung }}$ data hasil belajar kelompok kontrol lebih kecil dari $\chi_{\text {tabel }}^{2}\left(\chi^{2}\right.$ hitung $\left.<\chi_{\text {tabel }}^{2}\right)$, sehingga data Hasil Belajar IPS siswa kelompok kontrol berdistribusi normal.

Selanjutnya yaitu uji homogenitas varian. Berdasarkan uji homogenitas varian menggunakan uji $\mathrm{F}$ diketahui $\mathrm{F}_{\text {hitung }}$ skor hasil belajar IPS siswa kelompok eksperimen dan kontrol adalah 0,461 , sedangkan $F_{\text {tabel }}$ dengan $\mathrm{dk}_{\text {pembilang }}=21$ dan $\mathrm{dk}_{\text {penyebut }}=25$ pada taraf signifikansi $5 \%$ adalah 3,841. Hal ini berarti, varians data Hasil Belajar IPS siswa kelompok eksperimen dan kontrol adalah homogen.

Setelah diperoleh hasil dari uji prasyarat analisis data, dilanjutkan dengan pengujian hipotesis penelitian. Sebelum pengujian hipotesis terlebih dahulu dihitung GSn (gain score dinormalisasi) antara skor pre-test dan post-test. Perhitungan GSn (gain score dinormalisasi) dihitung dengan bantuan miscroshoft exel dengan ringkasan yang disajikan pada tabel 1.1 
Tabel 1 Perhitungan Gain Skor Ternormalisasi

\begin{tabular}{|c|c|c|c|c|c|c|}
\hline \multirow[t]{2}{*}{ NO } & \multicolumn{3}{|c|}{ Kelompok Eksperimen } & \multicolumn{3}{|c|}{ Kelompok Kontrol } \\
\hline & Pre-Test & $\begin{array}{c}\text { Post- } \\
\text { Test }\end{array}$ & GSn & Pre-Test & $\begin{array}{c}\text { Post- } \\
\text { Test }\end{array}$ & GSn \\
\hline 1 & 20 & 23 & 0,3 & 15 & 16 & 0,06 \\
\hline 2 & 19 & 21 & 0,18 & 16 & 17 & 0,07 \\
\hline 3 & 11 & 12 & 0,05 & 13 & 18 & 0,29 \\
\hline 4 & 10 & 12 & 0,1 & 18 & 19 & 0,08 \\
\hline 5 & 19 & 22 & 0,27 & 21 & 23 & 0,22 \\
\hline 6 & 16 & 18 & 0,14 & 20 & 22 & 0,2 \\
\hline 7 & 11 & 13 & 0,10 & 9 & 8 & $-0,04$ \\
\hline 8 & 17 & 19 & 0,15 & 10 & 10 & 0 \\
\hline 9 & 15 & 17 & 0,13 & 14 & 15 & 0,06 \\
\hline 10 & 13 & 16 & 0,17 & 20 & 20 & 0 \\
\hline 11 & 16 & 18 & 0,14 & 16 & 16 & 0 \\
\hline 12 & 19 & 21 & 0,18 & 21 & 23 & 0,22 \\
\hline 13 & 17 & 19 & 0,15 & 17 & 18 & 0,07 \\
\hline 14 & 10 & 11 & 0,05 & 12 & 12 & 0 \\
\hline 15 & 7 & 8 & 0,04 & 15 & 15 & 0 \\
\hline 16 & 20 & 22 & 0,02 & 14 & 15 & 0,06 \\
\hline 17 & 25 & 27 & 0,4 & 17 & 18 & 0,07 \\
\hline 18 & 22 & 25 & 0,37 & 21 & 22 & 0,11 \\
\hline 19 & 19 & 21 & 0,18 & 17 & 17 & 0 \\
\hline 20 & 10 & 11 & 0,05 & 14 & 15 & 0,06 \\
\hline 21 & 19 & 22 & 0,27 & 9 & 9 & 0 \\
\hline 22 & 10 & 12 & 0,1 & 19 & 19 & 0 \\
\hline 23 & 16 & 18 & 0,14 & & & \\
\hline 24 & 17 & 19 & 0,15 & & & \\
\hline 25 & 18 & 20 & 0,16 & & & \\
\hline 26 & 19 & 22 & 0,27 & & & \\
\hline Jumlah & 415 & 469 & 4,50 & 348 & 367 & 1,56 \\
\hline Mean & 15,96 & 18,04 & 0,17 & 15,81 & 16,68 & 0,06 \\
\hline Varians & 19,79 & 23,56 & 0,010 & 14,06 & 17,94 & 0,008 \\
\hline
\end{tabular}

Berdasarkan tabel di atas, tampak bahwa $t_{\text {hitung }}$ sebesar 9,167 , sedangkan, $t_{\text {tabel }}$ dengan $\mathrm{dk}=46$ pada taraf signifikansi $5 \%$ adalah 2,021. Hal ini berarti, $\mathrm{t}_{\text {hitung }}$ lebih besar dari $t_{\text {tabel }}\left(t_{\text {hitung }}>t_{\text {tabel }}\right.$ ) sehingga $H_{0}$ ditolak dan $H_{1}$ diterima. Dengan demikian, dapat diinterpretasikan bahwa terdapat pengaruh yang signifikan pada Hasil Belajar IPS antara siswa yang belajar dengan penerapan model pembelajaran Think Pair Share berbasis Tri Kaya Parisudha dan siswa yang tidak belajar dengan penerapan model pembelajaran Think Pair Share berbasis Tri Kaya Parisudha pada siswa kelas V SD di Gugus II Kecamatan Susut tahun pelajaran 2018/2019.

Model Pembelajaran Think Pair Share berbasis Tri Kaya Parisudha yang digunakan pada kelompok eksperimen dan kelompok kontrol yang tidak menggunakan Model Pembelajaran Think Pair Share berbasis Tri Kaya Parisudha dalam penelitian ini menunjukkan pengaruh yang berbeda pada Hasil Belajar IPS siswa.

Secara deskriptif, Hasil Belajar IPS siswa kelompok eksperimen lebih tinggi dibandingkan dengan siswa kelompok kontrol. Tinjauan ini didasarkan pada rata-rata skor dan kecenderungan skor Hasil Belajar IPS yang diperoleh kedua kelompok. Begitu pula yang tampak pada kurva poligon, yang mana sebaran data kelompok ini merupakan juling negatif. Artinya, sebagian besar skor siswa cenderung tinggi. Berbeda halnya pada 
kelompok kontrol, kurva sebaran data merupakan juling positif, yang artinya sebagian besar skor siswa cenderung rendah.

Temuan penelitian yang menunjukkan bahwa Model Pembelajaran Think Pair Share berbasis Tri Kaya Parisudha berpengaruh terhadap Hasil Belajar IPS siswa dengan kecenderungan sebagian besar skor siswa tinggi disebabkan oleh beberapa fase.

Fase Think (berpikir), siswa diberikan sebuah permasalahan. Pada fase ini siswa dilatih untuk berpikir secara individual untuk mengeluarkan kemampuannya dalam memecahkan sebuah permasalahan. Sehingga siswa dapat meningkatkan hasil belajar IPS. Sejalan dengan pendapat Suprijono (2009), fase think (berpikir) menjadikan pengetahuan siswa semakin berkembang. Selanjutnya Aris Shoimin (2014: 208) juga menyatakan bahwa Think Pair Share merupakan suatu "model pembelajaran kooperatif yang memberi siswa waktu untuk berpikir dan merespons serta saling bantu satu sama lain".

Fase Pairing (berpasangan), setelah siswa berpikir secara individual, guru meminta siswa berdiskusi dengan teman sebangkunya. Dengan berpasangan, siswa dapat berdiskusi dan saling melengkapi jawaban temannya, sehingga pengetahuan siswa semakin meluas dan sifatnya tidak terbatas. Dalam fase ini siswa juga dapat meningkatkan hasil belajar IPS. Sejalan dengan pendapat Suprijono (2009), fase pairing merupakan kegiatan bersama kelompok kecil yang terdiri dari 2 orang siswa. Tujuan dari pairing ini adalah untuk meningkatkan kerja sama siswa dalam kelompok dan berbagi ilmu dengan pasangannya.

Fase Sharing (berbagi), siswa menyampaikan hasil diskusi dengan pasangananya kedepan kelas kepada teman sekelasnya. Kegiatan sharing (berbagi) menjadikan siswa lebih aktif, percaya diri, dan menambah ingatan siswa terkait pemahamannya terhadap konsep. Sehingga dapat meningkatkan hasil belajar IPS. Sejalan dengan pendapat Suprijono (2009), kegiatan shering dapat menjadikan siswa lebih percaya diri dan melatih kemampuan siswa dalam berkomunikasi.

Fase think, pairing, dan share tersebut dapat memotivasi siswa untuk belajar lebih baik dan menemukan hal-hal yang bermakna dari fase-fase tersebut. Kesempatan tersebut akan memunculkan hasil pemikiran siswa secara murni dan didukung oleh penguatan dari pasangannya, sehingga berpengaruh terhadap kualitas pemahaman konsep siswa. Hal lain yang terjadi adalah pemahaman yang diperoleh tersebut tidak mudah dilupakan karena proses yang siswa lalui untuk memperolehnya merupakan kegiatan pembelajaran yang bermakna. Temuan tersebut didukung oleh pendapat Aris Shoimin (2014: 208) juga menyatakan bahwa Think Pair Share merupakan suatu "model pembelajaran kooperatif yang memberi siswa waktu untuk berpikir dan merespons serta saling bantu satu sama lain". Pembelajaran tersebut dilakukan melalui tahapan berpikir, berdiskusi, dan berbagi. Prosedur tersebut memberikan waktu yang cukup bagi siswa untuk mengkonstruksi pengetahuannya secara bermakna.

Temuan penelitian tersebut sesuai dengan hasil penelitian sebelumnya yang dilakukan oleh Mudjrimin (2013) menunjukkan bahwa penelitian ini bertujuan untuk mengetahui Pengaruh Model Pembelajaran Kooperatif Tipe TPS Terhadap Motivasi Berprestasi dan Hasil Belajar IPS Siswa Kelas V SD. Penelitian ini adalah ekperimen yang dilaksanakan di SDN Gugus 02 Kopang, melibatkan 60 siswa yang dikumpulkan dengan random sampling. Pembelajaran TPS sebagai variable bebas, motivasi berprestasi dan hasil belajar IPS sebagai variabel terikat. Data dikumpulkan dengan menggunakan kuisioner motivasi berprestasi dan tes hasil belajar IPS. Hasil penelitian menjukkan bahwa: (1) terdapat perbedaan secara signifikan motivasi berprestasi pada siswa yang belajar dengan pembelajaran TPS dengan siswa yang belajar dengan pembelajaran konvensional, (2) terdapat perbedaan secara signifikan hasil belajar IPS antara siswa yang belajar dengan 
pembelajaran TPS dengan siswa yang belajar dengan pembelajaran konvensional ,(3) terdapat perbedaan secara signifikan motivasi berprestasi dan hasil belajar IPS antara siswa yang belajar dengan pembelajaran TPS dengan siswa yang belajar dengan pembelajaran konvensional.

Berdasarkan paparan di atas, maka dapat disimpulkan bahwa model pembelajaran Think Pair Share berbasis Tri Kaya Parisudha berpengaruh terhadap Hasil Belajar IPS Siswa.

\section{SIMPULAN}

Berdasarkan hasil penelitian dan pembahasan di atas, dapat disimpulkan bahwa terdapat pengaruh yang signifikan pada Hasil Belajar IPS antara siswa yang belajar dengan penerapan model pembelajaran Think Pair Share berbasis Tri Kaya Parisudha dan siswa yang tidak belajar dengan penerapan model pembelajaran Think Pair Share berbasis Tri Kaya Parisudha pada siswa kelas V SD di Gugus II Kecamatan Susut tahun pelajaran 2018/2019.

Berdasarkan temuan yang diperoleh dari penelitian ini, maka ada beberapa saran yang dapat dikemukakkan adalah sebagi berikut.

1. Disarankan kepada kepala sekolah agar hasil penelitian ini dapat dijadikan dasar untuk mengambil kebijakan yang tepat dalam membina guru yang menjadi binaannya, sehingga guru memiliki kemampuan professional yang tinggi.

2. Disarankan kepada guru pengampu mata pelajaran IPS agar dapat melanjutkan penggunaan model pembelajaran Think Pair Share berbasis Tri Kaya Parisudha dalam proses pembelajaran secara berlanjut, sehingga hasil belajar siswa optimal.

3. Disarankan kepada siswa agar dapat mengikuti pembelajaran yang sudah dirancang dengan baik dan diharapkan siswa juga menyadari bahwa keaktifan siswa dalam proses pembelajaran IPS juga mempengaruhi hasil belajar sehingga nantinya siswa selalu berusaha untuk meningkatkan keaktifannya dalam menerima pembelajaran IPS.

4. Disarankan kepada peneliti lain diharapkan melakukan penelitian lanjutan yang sejalan dengan penelitian ini.

\section{DAFTAR PUSTAKA}

Asmariani, A. A. R. 2012. Tri Kaya Parisudha Sebagai Kontrol Sosial Prilaku Remaja Dalam Kehidupan Bermasyarakat di Era Globalisasi dan Modernisasi. IHDN Denpasar, 1-16.

Astawan, I. G, dkk. 2018. Teori dan Aplikasi Model Pembelajaran Trikaya Parisudha. (D. P. Parniti, Ed.). Bali: Undiksha Press.

Budiarta, I. K., \& Krismayani, N. W. 2018. Improving Speaking Skill and Developing Character of the Students through Collaboration of Think Pair Share and the Concept of Tri Kaya Parisudha. Journal Pendidikan Bahasa Inggri Universitas Mahasaraswati Denpasar, 565-573.

Irmayanti, dkk. 2012. Pengaruh Model Pembelajaran Group Investigation Berbasis Kearifan Lokal Tri Kaya Parisudha Terhadap Hasil Belajar IPS. Singaraja, Volume 5 Nomor 2.

Kosasih, E. 2014. Strategi Belajar dan Pembelajaran Implementasi Kurikulum 2013. Bandung: Yrama Widya.

Lasmawan, Wayan. 2010. Menelisik Pendidikan IPS. Singaraja: Mediakom Indonesia Press Bali

Maryatun, I. B., \& Kusumadewi, N. 2012. Penerapan Students Centered Approach pada Pembelajaran Taman Kanak-Kanak Kelompok B ( Studi Kasus di Sekolah Laboratorium Rumah Citta ). Jurnal Pendidian Anak, 1, Edisi 1. 
Mudjrimin, dkk. 2013. Pengaruh Model Thini Pair Share Terhadap Motivasi Berprestasi Dan Hasil Belajar Ips Siswa Kelas V SDN Gugus 02 Kopang. E-Journal Program Pascasarjana Universitas Pendidikan Ganesha, 3(2).

Shoimin, Aris. 2014. 68 Model Pembelajaran Inovatif dalam Kurikulum 2013. Yogyakarta: Ar-Ruzz Media.

Suprijono, A. 2009. Cooperatif Learning dan Aplikasi Paikem. Yogyakarta: Pustaka Belajar.

Susanto, A. 2013. Teori Belajar dan Pembelajaran di Sekolah Dasar. Jakarta: Kencana Prenada Media Group.

Trianto. 2007. Model- Model Pembelajaran Inovatif Berorientasi Konstruktivistik. (F. Yustianti, Ed.) (4th ed.). Jakarta: PT. Bumi Aksaraa.

Wulandari, P, dkk. 2018. Pengaruh Model Pembelajaran Think Pair Share Berbasis Penilaian Portofolio Terhadap Kompetensi Pengetahuan IPA Siswa Kelas IV SD Negeri Gugus Kapten Kompyang Sujana Denpasar Barat Tahun 2017/ 2018. E-Journal PGSD Universitas Pendidikan Ganesha, 6 No.1, 1-9 